\title{
MULTIDRUG RESISTANT INFECTIONS IN INTENSIVE CARE UNITS
}

\author{
Andonovska Biljana, ${ }^{1}$ Kotevska Vesna, ${ }^{2}$ Andonovski Alan ${ }^{1}$ \\ ${ }^{1}$ University Clinic for Orthopedic Surgery, Traumatology, \\ Anesthesiology and Intensive Care, Skoplje, Republic of North Macedonia \\ ${ }^{2}$ Institute for Microbiology and Parasitology, Faculty of medicine, \\ University "Ss Cyril and Methodius" Skopje, Republic of North Macedonia
}

Primljen/Received 05. 07. 2020. god.

Abstract: Background: Intensive care units (ICU) are often the epicentre of development of infections caused by multidrug resistant (MDR) organisms.

Purpose: The aim of our study was to determine the prevalence and types of ICU-acquired infections, pathogens associated with such infections and to determine the antibiotic resistance pattern of the presented pathogens.

Material and methods: In the study were included 130 patients hospitalized into the surgical ICU of the University Clinic for Anesthesiology and Intensive Care in Skopje in period of 2 months, April -Jun, 2017., who developed infection after at least 72 hours of their hospitalization. In all of them the pathogens and their antibiotic resistance pattern were identified.

Results: Twenty of 130 (15.4\%) patients developed ICU-acquired infection. Most common infections were pneumonia $(50 \%)$ and surgical site $(30 \%)$ infections. Gram-negative organisms were more common isolated than Gram-positive organisms ( $83 \%$ vs. $17 \%$ ). The most common isolated bacteria were Acinetobacter species $(30,41.7 \%)$ and Pseudomonas aeruginosa $(15,20.8 \%)$. All isolated species were MDR organisms resistant to the most used antibiotics like Cephalosporins, Gentamicin, Ciprofloxacin and Clindamycin. Pseudomonas aeruginosa and Acinetobacter species were sensitive to Colistin, Methicillin-resistant Staphylococcus aureus (MRSA) to Vancomycin and Linezolid and Enterococcus only to Linezolid. Klebsiella pneumoniae and Proteus mirabilis showed low resistance only to Amikacin and Carbapenems.

Conclusions: Our study obtained local data about the prevalence and types of ICU-acquired infections, types of pathogens and their antibiotic resistance pattern. Based on this knowledge, clinicians can choose
Prihvaćen/Accepted 16. 11. 2020. god.

appropriate antibiotics, avoiding antibacterial drug overuse and MDR bacteria development.

Keywords: intensive care unit acquired infections, multidrug resistant bacteria, antibiotic resistance.

\section{INTRODUCTION}

Nosocomial infections or ICU-acquired infections are infections which are developed in intensive care units (ICU). The incidence of ICU-acquired infections varies between $12-49 \%$ and most of the ICU hospitalized patients develop an infection within 6 days of their admission $(1,2)$. Because of exposure to multiple invasive procedures which compromise the anatomical barriers' defences, and because of impairment of protective mechanisms such as cough reflex or acid gastric ambient by sedative drugs critically ill patients are more prone to infections than other patients $(3,4)$. Their inadequate immune response induced by trauma, surgery and sepsis is another factor that leads to higher frequency of infections in these patients $(3,4)$. Bloodstream infections, lower respiratory tract infections, urinary tract infections and surgical site infections are most common infections seen in these ICU patients (5). According to some studies $(6,7)$ about $40 \%$ of the total expenditure in the ICU is due to infections which has increased the death rate of the hospitalized patients by two times.

The increased prevalence of infections caused by multidrug resistant (MDR) organisms is another problem, which is more common in ICU than in other departments (8). Inappropriate and irrational use of antimicrobial agents especially overuse of broad-spectrum antibiotics leads to development and spread of drug-resistant microorganisms. According to some studies (9, 
$10,11)$, the rate of inappropriate or incorrect antibiotic prescriptions in ICUs varies from $30 \%$ to $60 \%$ in hospitalized patients. The prevalence of infections caused by multidrug resistant (MDR) bacteria in ICU is different in the different regions of the world. DEFINE study showed a $14.1 \%$ rate of MDR infections in critically ill patients with pneumonia in North America. EUROBACT study showed on average a 47.8\% MDR infections in critically ill patients with bloodstream infections conducted in 24 ICUs distributed worldwide including $20.5 \%$ and $0.5 \%$ of isolated microorganisms with extensively drug-resistant (EDR) and pan-drug-resistant (PDR) patterns $(12,13)$.

Having in mind the fact that there is a considerable variation in the presented MDR pathogens across the countries and geographical region, locally obtained data can be used to predict the resistance of the locally persistent pathogens and to make the choice of antibiotics according to the antimicrobial susceptibility pattern when infections occur.

The aim of our study was to determine the prevalence of ICU-acquired infections, to determine the types and pathogens that cause such infections and to determine the antibiotic resistance pattern of the presented pathogens.

\section{PATIENTS AND METHODS}

130 patients admitted into the surgical intensive care unit of the University Clinic for Anesthesiology, Reanimation and Intensive Care in Skopje, Republic of North Macedonia, and hospitalized in the period of two months (April-Jun, 2017) were included in the study. All clinical data for these patients according to prevalence of ICU-acquired infections,types and pathogens that cause such infections and the antibiotic resistance pattern of the presented pathogens were retrieved from the official report of the Commission for prevention of intrahospital infections. All procedures performed in study involving human participants were in accordance with the ethical standards of the institutional and/or national research committee and with the 1964 Helsinki declaration. Only patients who developed clinically manifested infections after at least 72 hours of hospitalization were considered to have ICU acquired infections and were included in the study. Specimens were collected under strict asepsis and sent to the laboratory of the Institute of Microbiologyin Skopje for further analyses. The specimens include urine, tracheal aspirates, blood, urine, and wound swabs. Standard microbiological methods were used in order to identify the presented pathogens (14). Their antibiotic susceptibility was also tested using the antibiotics disk diffusion and Vitec technique. Testing included several antibiotics: Ceftriaxone, Cefixime, Clindamycin, Amikacin, Ciprofloxacin, Vancomycin, Linezolid, Meropenem, Imipenem, Gentamicin, Cotrimoxazole and Colistin. Risk factors for development of ICU-acquired infections were also analyzed.

For the statistical analysis, SPSS 12.0 software was used. Data were presented using means, range and proportions.Comparison of differences was performed with the sample t-test. Statistical significance was defined as $p$-value $<0.05$.

\section{RESULTS}

A total of 130 patients hospitalized in ICU were included in the study. Among them 42 (33.8\%) were female and $88(66.2 \%)$ were male patients. The mean age of patients was $51.6 \pm 17.1$ years (range 14 to 84 years). Most patients $(36,27.7 \%)$ were between 60 and

Table 1. Distribution of patients with ICU-acquired infectionsaccording to age and sex

\begin{tabular}{|l|c|c|c|}
\hline \multicolumn{1}{|c|}{ Characteristics } & Number of patients & $\begin{array}{c}\text { Number of patients } \\
\text { with ICUacquiredinfection }\end{array}$ & Prevalence (\%) \\
\hline Sex & 42 & & \\
\hline Female & 88 & 20 & $22.73 \%$ \\
\hline Male & & & \\
\hline Age (years) & 10 & 2 & $20.2 \%$ \\
\hline$\leq 19$ & 10 & 6 & $60.0 \%$ \\
\hline $20-29$ & 14 & 4 & $28.6 \%$ \\
\hline $30-39$ & 22 & 2 & $7.1 \%$ \\
\hline $40-49$ & 28 & 2 & $5.6 \%$ \\
\hline $50-59$ & 36 & 2 & $33.3 \%$ \\
\hline $60-69$ & 6 & 2 & \\
\hline $70-79$ & 4 & $/$ & \\
\hline $80>$ & & & \\
\hline
\end{tabular}


Table 2. Types of ICU-acquired infections

\begin{tabular}{|l|c|c|}
\hline \multicolumn{1}{|c|}{ Site of infection } & $\begin{array}{c}\text { Number of patients } \\
\text { with ICU-acquired infections }\end{array}$ & Prevalence (\%) \\
\hline Lower respiratory tract infection & 10 & 50 \\
\hline Surgical site infection & 630 & \\
\hline Urinary tract infection & 210 & \\
\hline Other site infection & 210 & \\
\hline
\end{tabular}

Table 3. Antibiotic resistance pattern (\%) of isolated organisms

\begin{tabular}{|l|c|c|c|c|c|c|}
\hline \multirow{2}{*}{ Antibiotics } & \multicolumn{7}{|c|}{ Organisms } \\
\cline { 2 - 7 } & Acinetob. spp & P.aeruginosa & MRSA & Enterococcus & K1. pneumoniae & Pr. mirabilis \\
\hline Ceftriaxone & 100 & 100 & 100 & 80 & 90 & 90 \\
\hline Cefepim & 83.4 & 60 & 100 & 60 & $/$ & 70 \\
\hline Clindamycin & 100 & $/$ & 90 & 80 & 90 & $/$ \\
\hline Amikacin & 83.4 & 40 & 80 & 70 & 30 & 30 \\
\hline Ciprofloxacin & 100 & 40 & 80 & 70 & 60 & 50 \\
\hline Vancomycin & $/$ & $/$ & 0 & 20 & $/$ & $/$ \\
\hline Linezolid & $/$ & $/$ & 0 & 0 & $/$ & $/$ \\
\hline Meropenem & 100 & 40 & $/$ & 70 & 20 & 30 \\
\hline Imipenem & 92 & 20 & $/$ & $/$ & 10 & 20 \\
\hline Gentamicin & 92 & 40 & 80 & 70 & 70 & 60 \\
\hline Cotrimoxazol & 50 & $/$ & 60 & $/$ & $/$ & 70 \\
\hline Colistin & 0 & 0 & $/$ & 60 & 30 & 100 \\
\hline
\end{tabular}

Acinetobacter species (Acinetob. spp); Pseudomonas aeruginosa (P. aeruginosa); Methicillin Resistant Staphylococcus aureus (MRSA); Enterococcus (Enterococcus); Klebsiella pneumoniae V. aerogenes (Kl. pneumoniae); Proteus mirabilis (Pr. mirabilis).

69 years old. Twenty of the 130 hospitalized patients developed ICU-acquired infection after at least 72 hours of hospitalization, giving a prevalence rate of $15.4 \%$.All of them were male patients, hence the prevalence of ICU-acquired infections in male patients hospitalized in ICU was $22.73 \%$ (Table 1). The prevalence of ICU-acquired infections was highest in younger patients, between 20 to 29 years of age (Table 1).

According to the distribution of the types of ICU-acquired infections (Table 2) lower respiratory tract infection (pneumonia) was the most common infection presented in $10(50 \%)$ of the infected patients. Surgical site infections were presented in $6(30 \%)$ of the infected ICU patients and other infections had less prevalence (Table 2).

Seventy two of 132 taken specimens were positive. In patients with ICU-acquired infections the frequency of isolated Gram-negative organisms was significantly higher than that of the Gram-positive organisms ( $83 \%$ vs. $17 \%, \mathrm{p} \leq 0.005)$. The most common found isolates (Figure 1) were those of Acinetobacter species (30, 41.7\%) and Pseudomonas aeruginosa (15, 20.8\%). Fungal growth was also seen in $4(5.5 \%)$ of the isolated cultures.

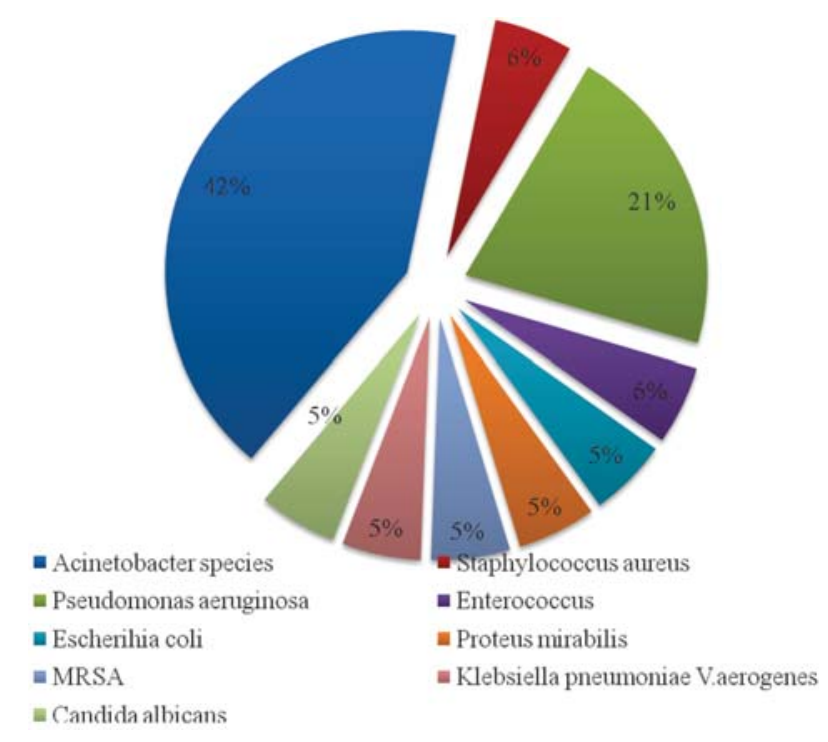

Figure 1. Distribution of pathogens isolated in ICU infected patients

The obtained results (Table 3 ) showed a high level of antibiotic resistance in both groups of organisms. Acinetobacter species isolates showed high resistance to most examined antibiotics (83-100\%) and medium resistance to Cotrimoxazole (50\%). Pseudomonas 
aeruginosaisolates showed high resistance to Ceftriaxone $(100 \%)$, medium resistance (40-60\%) to Cefepime, Amikacin, Ciprofloxacin, Gentamicin and Meropenem and low resistance to Imipenem (20\%). Both bacteria isolates were sensitive to Colistin. Klebsiella pneumoniae isolatesshowed high resistance (70-90\%) to Ceftriaxone, Clindamycin and Gentamicin, medium resistance $(60 \%)$ to Ciprofloxacin and low resistance (10-30\%) to Amikacin, Colistin and Carbapenems. Proteus mirabilis showed high resistance to Colistin $(100 \%)$ and Ceftriaxone (90\%), and low resistance to Amikacin and Carbapenems (20-30\%). All MRSA isolates showed high resistance over $60 \%$ to all examined antibiotics except to Vancomycin and Linezolid. Enterococcus isolates showed similar antibiotic resistance pattern as MRSA isolates. The only difference was the resistance to Vancomycin found in $20 \%$ of the examined isolates.

In general, the results showed a high level of antibiotic resistance to the most frequently used antibiotics like Cephalosporins, Gentamicin, Ciprofloxacin and Clindamycin.

\section{DISCUSSION}

Because of antibacterial drugs overuse, antibacterial drugs have become less effective or even ineffective, resulting in occurrence of multidrug resistant organisms.

According to the U.S. Centers for Disease Control and Prevention (CDC), each year in the United States, multidrug resistant organisms cause approximately 2 million cases of illnesses and 23,000 deaths (15). MDR organisms are organisms with acquired non-susceptibility to at least one agent in three or more antimicrobial categories which were previously proposed by the Clinical Laboratory Standards Institute (CLSI), the European Committee on Antimicrobial Susceptibility Testing (EUCAST) and the United States Food and Drug Administration (FDA) (16).

These problematic pathogens, known as the "ESKAPE" pathogens group, which tend to be resistant to the activity of many antibiotics include: Enterococcus faecium, Staphylococcus aureus, Klebsiella pneumoniae, Acinetobacter baumannii, Pseudomonas aeruginosa and Enterobacter species. Clostridium difficile can be also added to the list according to the literature (17). The mechanism of antimicrobial resistance in these pathogens can be explained by: (a)enzymatic degradation of antibiotics by hydrolytic enzymes, (b) alteration of bacterial proteins or target sites, and (c) changes in membrane permeability to antibiotics either by penetration or by expulsion of the actual antibiotic from within the bacteria (18). The Centers for Disease
Control and Prevention (CDC) prioritized bacteria into one of three categories: concerning, serious and urgent (19).

In the different regions of the world there is a different prevalence of infections caused by multidrug resistant bacteria in ICUs. EPIC II study showed that about $51 \%$ of the ICU patients were considered to be infected with respiratory infection. According to the study, Staphylococcus aureus was isolated in $20.5 \%$ of the cases and the Gram-negative organisms (E. coli, Enterobacter spp., Klebsiella spp., Pseudomonas spp. and Acinetobacter spp.) were found in $62.2 \%$ of the patients. EUROBACT study showed an average of $47.8 \%$ MDR rate. According to this study different countries showed different MDR rate ranging from $8 \%$ in Australia to more than $75 \%$ in Turkey, Greece, Croatia and Serbia $(12,13)$.

In our study we found that ICU-acquired infections had a low prevalence rate of $15.4 \%$. Our results corresponded with those presented by Sannusi (20), but were opposite to the results published by Rosenthal, Meric, Erbay, Magnason and Makanjuola (21-25) where higher prevalence rates of $26-39 \%$ were presented. Similar to the study by Makanjuola et al. (25) most of our patients with ICU-acquired infections were males aged from 20 to 29 years.

The most frequently ICU-acquired infections were pneumonia (50\%), surgical site infections (30\%) and urinary tract infections $(10 \%)$. Other site infections which included primary bloodstream infections were found in less than $10 \%$ of the hospitalized patients. Our study population consisted of patients who were on mechanical ventilation, which is a risk factor for occurrence of ventilator-associated pneumonia (VAP).Similar findings have been reported by Meric et al. (22) Erbay et al. (23), de Leon-Rosales et al. (26), Richards et al. (27),Vincent et al. (8), Sheth et al. (28) and Makanjuola et al. (25). This means that considering the results from the previous studies pneumonia is the most common ICU-acquired infections in Nigeria, Turkey, Mexico, United Statesand India, although the study by Sanusi et al. (20), contrary to the study by Makanjuola et al. (25), showed that urinary tract infection were the most common ICU-acquired infections in Nigeria. Rosenthal et al. (21) found blood stream infections as the most common infections in ICUs in Argentina.

In our study Gram-negative bacteria isolates were more common than Gram-positive bacteria isolates ( $83 \%$ vs. $17 \%, p \leq 0.005)$. Similar to our results, in Asiancountries including India (29-35) and in some African countries (25), most of the isolates obtained from ICU patients weregram-negative organisms such as Psudomonas aeruginosa, Echerichia coli, Klebsiella pneumonia and Acinetobacter species, followed by 
gram-positive organismslike Staphylococcus and Enterococcus. Acinetobacter species and Pseudomonas aeruginosa were the most common isolated Gram-negative bacteria in our study with prevalence of $41.7 \%$ and $20.8 \%$, respectively. According to some studies Acinetobacter species are the most common cause of ICU infection especially in immunocompromised patients $(33,34)$. Pseudomonas aeruginosa, according to some studies $(6,23,25,28,33)$ appears to predominate globally. The low prevalence of Gram-positive bacteria (Staphylococus aureus, MRSA and Enterococcus) in our study did not correlate with the prevalence presented in the most previously published studies $(22$, 20, 23, 34, 35). Only the study of Qadeer et al. (33) performed in Pakistan showed similar prevalence rates as ours.

The most important finding was the antibiotic resistance of the most common bacteria isolated in our study. According to our results, there was a very high level of resistance to antibiotics because isolated pathogens in our study showed resistance to multiple antibiotics. We found that MRSA was sensitive to Vancomycin and Linezolid and Enterococcus only to Linezolid. Pseudomonas aeruginosa and Acinetobacter species were both sensitive only to Colistin. This finding corresponds with the reports of the CDC, which presented that $63 \%$ of the infections with Acinetobacter in the United States were multidrug resistant infections. According to these reports, Acinetobacter causes approximately 12,000 healthcare-associated infections annually in the United States and approximately 1 million cases per year in the world globally. Other species like Klebsiella pneumonia and Proteus mirabilis showed low resistance only to Amikacin and Carbapenems (Meropenem and Imipenem). Our results did not correlate with those reported by Savanur et al. (32), who presented a high resistance of Klebsiella isolates, except to Cephalosporins and Gentamicinas well as to Amikacin and Carbapenems because of the persistence of carbapenemase-producing Klebsiella pneumoniae bacteria across North America and other word regions. All isolated bacteria species in our study were resistant to the most frequently used antibiotics like Cephalosporins, Gentamicin, Ciprofloxacin and Clindamycin. It means that ICU-acquired infections were caused by MDR organisms.

Our study has some limitations. Firstly, we did not identify some risk factors for occurrence of infections by MDR bacteria among ICU patients: central venous access, pulmonary artery catheterization, stress ulcer prophylaxis, urinary catheterization, mechanical ventilation, trauma, ICU length of stay and, mostly, a previous history of infection or colonization by MDR microorganisms. Secondly, the follow-up time period was only two months, which according to us is not sufficient for obtaining relevant results.

\section{CONCLUSION}

Having in mind the fact that there is a considerable variation in the presented MDR pathogens across the countries and geographical regions, the advantages of our study are as follows: it obtained data about the prevalence and types of ICU-acquired infections, determined the pathogens associated with these infections and determined the resistance pattern of the presented pathogens. This knowledge can be used to predict the resistance of the locally persistent pathogens and to make the choice of antibiotics according to the antimicrobial susceptibility pattern when infections occur. Thus, antibacterial drug overuse could be avoided, reducing the risk of MDR bacteria development.

\section{CLINICAL RELEVANCE}

Antibiotic resistance is a major upcoming problem in today's clinical practice, especially in patients with ICU-acquired infections. Local data of the prevalence and types of ICU-acquired infections, pathogens types and their resistance pattern are very important in order to obtain good antibiotic response, reducing morbidity and mortality rates and avoiding drug overuse and MDR bacteria development. Studies like ours give an opportunity for early targeted antibiotic therapy reducing the number of antibiotics or using narrower spectrum drugs. This is very important considering that prompt administration with appropriate antibiotics within 1 hour of recognizing infection, sepsis or septic shock has shown to improve survival in these patients with MDR ICU-acquired infections.

Conflict of Interests: The authors declare that there are no conflicts of interest related to this article.

Funding: None

\section{Licensing}

This work is licensed under a Creative Commons Attribution 4.0 International (CC BY 4.0) License. 


\title{
Sažetak
}

\section{OTPORNOST INFEKCIJANA VIŠESTRUKE LEKOVE U JEDINICAMAINTENZIVNE NEGE}

\author{
Andonovska Biljana, ${ }^{1}$ Kotevska Vesna, ${ }^{2}$ Andonovski Alan ${ }^{1}$ \\ ${ }^{1}$ University Clinic for Orthopedic Surgery, Traumatology, \\ Anesthesiology and Intensive Care, Skoplje, Republic of North Macedonia \\ ${ }^{2}$ Institute for Microbiology and Parasitology, Faculty of medicine, \\ University "Ss Cyril and Methodius" Skopje, Republic of North Macedonia
}

Uvod: Jedinice intenzivne nege (JIN) su često epicentar razvoja infekcija izazvanih mikroorganizmima otpornim na višestruke lekove (MDR).

Cilj: Cilj studije je da se utvrdi prevalenca i tipovi infekcija stečenih u JIN-u, utvrde patogeni povezani sa ovim infekcijama i utvrdi obrazac antibiotske rezistencije kod prisutnih patogena.

Materijal i metode: U studiju je uključeno 130 pacijenata hospitalizovanih u hirurškim JIN univerzitetske Klinike za anesteziologiju i intenzivnu negu u Skoplju tokom perioda od 2 meseca, April-Jun 2017, koji su razvili infekciju najmanje posle 72 sata od hospitalizacije. Kod svih njih identifikovani su patogeni i ispitana multirezistentnost na antibiotike.

Rezultati: Dvadeset od 130 (15,4\%) pacijenata razvilo je infekcije stečene u JIN-u. Načešće infekcije bile su pneumonija (50\%) i hirurške infekcije (30\%). Gram-negativni organizmi bili su češće izolovani od Gram-pozitivnih ( $83 \%$ vs. $17 \%$ ). Najčešće izolovane bakterije bile su Acinetobacter species (30, 41,7\%) i

\section{REFERENCES}

1. Esen S, Leblebicioglu H. Prevalence of nosocomial infections at intensive care units in Turkey: a multicentre 1-day point prevalence study. Scand J Infect Dis. 2004; 36(2): 144-8.

2. Ylipalosaari P, Ala-Kokko TI, Laurila J, Ohtonen P, Syrjala H. Epidemiology of intensive care unit (ICU)- acquired infections in a 14-month prospective cohort study in a single mixed Scandinavian university hospital ICU. Acta Anaesthesiol Scand. 2006; 50(10): 1192-7.

3. Hotchkiss RS, Monneret G, Payen D. Immunosuppression in sepsis: a novel understanding of the disorder and a new therapeutic approach. Lancet Infect Dis. 2013; 13(3): 260-8.

4. Conway Morris A, Datta D, Shankar-Hari M, Stephen J, Weir CJ, Rennie J et al. Cell-surface signatures of immune dysfunction risk-stratify critically ill patients: INFECT study. Intensive Care Med. 2018; 44(5): 627-35.

5. Cairns S, Reilly J, Booth M. Prevalence of healthcare-associated infection in Scottish intensive care units. J Hosp Infect. 2010; 76(4): 308-10.

6. Vincent JL, Rello J, Marshall J, Silva E, Anzueto A, Martin $\mathrm{CD}$, et al. International study of the prevalence and outcomes of infection in intensive care units. JAMA. 2009; 302(21): 2323-9.

7. Ylipalosaari P, Ala-Kokko TI, Laurila J, Ohtonen P, Syrjala H. Intensive care acquired infection is an independent
Pseudomonas aeruginosa (15, 20,8\%). Sve izolovane vrste su bili mikroorgaanizmi otporni na višestruke lekove, otporni na najčešće korišćene antibiotike kao što su Cephalosporins, Gentamicin, Ciprofloxacin and Clindamycin. Pseudomonas aeruginosa and Acinetobacter sojevi su bili osetljivi na Colistin. Methicillin-rezistentan Staphylococcus aureus $(M R S A)$ je bio osetljiv na Vankomicin i Linezolid, a Enterococcus samo na Linezolid. Klebsiella pneumoniae i Proteus mirabilis su pokazali nisku rezistenciju samo na Amikacin i Karbapeneme.

Zaključak: Naša studija prikupila je podatke o prevalenci i tipovima infekcija stečenih u JIN-u, tipovima patogena i obrascu njihove otpornosti na antibiotike. $\mathrm{Na}$ osnovu ovih saznanja kliničari mogu da izaberu odgovarajuće antibiotike, izbegavajući prekomernu upotrebu antibiotika i ravoj multirezistentnih sojeva bakterija.

Ključne reči: infekcije stečene u jedinicama intenzivne nege, multirezistentne bakterije, antibiotska rezistencija.

risk factor for hospital mortality: a prospective cohort study. Crit Care. 2006; 10(2): R66.

8. Vincent JL, Bihari DJ, Suter PM, Bruining HA, White $\mathrm{J}$, Nicolas-Chanoin $\mathrm{MH}$ et al. The prevalence of nosocomial infection in intensive care units in Europe. Results of the European Prevalence of Infection in Intensive Care (EPIC) Study. EPIC International Advisory Committee. JAMA. 1995; 274(8): 639-44.

9. McGowan JE. Antimicrobial resistance in hospital organisms and its relation to antibiotic use. Rev Infect Dis. 1983; 5(6): 1033-48.

10. Marr JJ, Moffet HL, Kunin CM. Guidelines for improving the use of antimicrobial agents in hospitals: a statement by the Infectious Diseases Society of America. J Infect Dis. 1988; 157(5): 869-76.

11. Luyt CE, Brechot N, Trouillet JL, Chastre J. Antibiotic stewardship in the intensive care unit. Crit Care 2014; 18(5): 480.

12. Lat I, Daley MJ, Shewale A, Pangrazzi MH, Hammond D, Olsen KM; DEFINE study group and the Discovery Research Network. A multicenter, prospective, observational study to determine predictive factors for multidrug resistant pneumonia in critically ill adults: The DEFINE study. Pharmacotherapy $2019 ; 39(3): 253-60$.

13. Tabah A, Koulenti D, Laupland K, Misset B, Valles J, Bruzzi de Carvalho F, et al. Characteristics and determinants of outcome of hospital-acquired bloodstream infections in intensi- 
ve care units: the EUROBACT International Cohort Study. Intensive Care Med 2012; 38(12): 1930-45.

14. Cowan S. Cowan and Steel's manual for the identification of medical bacteria. In: Barrow GI, Feltham RKA, editors. Third Edit. Cambridge: Cambridge University Press; 2003.

15. Ventola CL. The antibiotic resistance crisis: Part 1: Causes and threats. PT. 2015; 40(4): 277-83.

16. Magiorakos AP, Srinivasan A, Carey RB, Carmeli Y, Falagas ME, Giske CG et al. Multidrug-resistant, extensively drug-resistant and pandrug-resistant bacteria: an international expert proposal for interim standard definitions for acquired resistance. Clin Microbiol Infect. 2012; 18(3): 268-81.

17. Boucher HW, Talbot GH, Bradley JS, Edwards JE, Gilbert D, Rice LB, et al. Bad bugs, no drugs: No ESKAPE! An update from the Infectious Diseases Society of America. Clin Infect Dis. 2009; 48(1): 1-12.

18. Ferrer R, Martin-Loeches I, Phillips G, Osborn TM, Townsend S, Dellinger RP et al. Empiric antibiotic treatment reduces mortality in severe sepsis and septic shock from the first hour: Results from a guideline-based performance improvement program. Crit Care Med. 2014; 42(8): 1749-55.

19. Antibiotics Resistance Threat in the US. US Department of Health \& Human Services; Centers for Disease Control and Prevention [Internet]. 2013. Available from: http://www.cdc.gov/ drugresistance/pdf/ar-threats-2013-508.pdf

20. Sanusi AA, Osinaike BB, Fayemiwo SA, Nwadike VU, Akinyemi AO, Adigun TA et al. Epidemiology of bacteria colonization and ICU acquired infection in a Nigerian tertiary hospital. African J Infect Dis. 2015; 9(2): 61-6.

21. Rosenthal VD, Guzman S, Orellano PW. Nosocomial infections in medical-surgical intensive care units in Argentina: attributable mortality and length of stay. Am J Infect Control. 2003; 31(5): 291-5.

22. Meric M, Willke A, Caglayan C, Toker K. Intensive care unit-acquired infections, incidence, risk factors and associated mortality in a Turkish university hospital. Jpn J Infect Dis. 2005; 58(5): 297-302.

23. Erbay H, Yalcin AN, Serin S, Turgut H, Tomatir E, Cetin B, et al. Nosocomial infections in intensive care unit in a Turkish university hospital: a 2-year survey. Intensive Care Med. 2003; 29(9): 1482-8.

24. Magnason S, Kristinsson KG, Stefansson T, Erlendsdottir H, Jonsdottir K, Kristjansson M et al. Risk factors and outcome in ICU-acquired infections. Acta Anaesthesiol Scand. 2008; 52(9): 1238-45.

\section{Correspondence to/Autor za korespondenciju}

Biljana Andonovska

University Clinic for Orthopedic Surgery, Traumatology,

Anesthesiology and Intensive Care,

Skoplje, Republic of North Macedonia.

Tel.: +38970212880

E-mail: andonovska.biljana1@gmail.com
25. Makanjuola OB, Fayemiwo SA, Okesola AO, Gbaja A, Ogunleye VA, Kehinde AO, et al. Pattern of multidrug resistant bacteria associated with intensive care unit infections in Ibadan, Nigeria. Ann Ib Postgrad Med. 2018; 16(2): 162-9.

26. Ponce de León-Rosales SP, Molinar-Ramos F, Domínguez-Cherit G, Rangel-Frausto MS, Vázquez-Ramos VG. Prevalence of infections in intensive care units in Mexico: a multicenter study. Crit Care Med. 2000; 28(5): 1316-21.

27. Richards MJ, Edwards JR, Culver DH, Gaynes RP. Nosocomial infections in combined medical-surgical intensive care units in the United States. Infect Control Hosp Epidemiol. 2000; 21(8): 510-5.

28. Sheth KV, Patel TK, Malek S, Tripathi CR. Antibiotic sensitivity pattern of bacterial isolates from the ICU of a tertiary care hospital in India. Trop J Pharm Res. 2012; 11(6): 991-9.

29. Lautenbach E, Synnestvedt M, Weiner MG, Bilker WB, Vo L, Schein J, et al. Imipenem resistance in Pseudomonas aeruginosa: emergence, epidemiology, and impact on clinical and economic outcomes. Infect Control Hosp Epidemiol. 2010; 31(1): 47-53.

30. Lautenbach E, Polk RE. Resistant gram-negative bacilli: a neglected healthcare crisis? Am J Health Syst Pharm. 2007; 64(23 suppl 14): S3-21.

31. Dellit TH, Owens RC, McGowan JE, Jr, Gerding DN, Weinstein RA, Burke JP, et al. Infectious Diseases Society of America and the Society for Healthcare Epidemiology of America guidelines for developing an institutional program to enhance antimicrobial stewardship. Clin Infect Dis. 2007; 44(2): $159-77$.

32. Sevanur SS, Gururay H. Study of antibiotic sensitivity and resistance pattern of bacterial isolates in intensive care unit setup of a tertiary care hospital. Indian J Crit Care Med. 2019; 23(12): 547-55.

33. Qadeer A, Akhtar A, Ain QU, Saadat S, Mansoor S, Assad S, et al. Antibiogram of medical intensive care unit at tertiary care hospital setting of Pakistan. Cureus. 2016; 8(9): e809.

34. Tan R, Liu J, Li M, Huang J, Sun J, Qu H. Epidemiology and antimicrobial resistance among commonly encountered bacteria associated with infections and colonization in intensive care units in a university-affiliated hospital in Shanghai. J Microbiol Immunol Infect. 2014; 47(2): 87-94.

35. Ak O, Batirel A, Ozer S, Colakoglu S. Nosocomial infections and risk factors in the intensive care unit of a teaching and research hospital: a prospective cohort study. Med Sci Monit. 2011; 17(5): PH29-34. 